\title{
Kombinasi Metode AHP dan TOPSIS untuk Rekomendasi Penerima Beasiswa SMK Berbasis Sistem Pendukung Keputusan
}

\author{
M. Rasyid Ridho' ${ }^{1}$, Hairani Hairani ${ }^{2, *}$, Kurniadin Abd Latif ${ }^{3}$, Rifqi Hammad ${ }^{4}$ \\ ${ }^{12}$ Fakultas Teknik dan Desain, Ilmu Komputer, Universitas Bumigora, Mataram, Indonesia \\ ${ }^{34}$ Fakultas Teknik dan Desain, Rekayasa Perangkat Lunak, Universitas Bumigora, Mataram, Indonesia \\ Email: ${ }^{1}$ mrasyidridho@gmail.com, ${ }^{2,}$ hairani@universitasbumigora.ac.id, \\ ${ }^{3}$ kurniadin@universitasbumigora.ac.id, ${ }^{4}$ rifqi.hammad@univeristasbumigora.ac.id \\ *) Email Penulis Utama
}

\begin{abstract}
Abstrak-SMK 2 Negeri Mataram merupakan lembaga pedidikan yang terteletak dikota mataram. Setiap tahunnya pihak SMK Negeri 2 Mataram (pihak humas) melakukan seleksi beasiswa bagi siswa yang memiliki nilai akademik bagus tetapi tidak mampu secara ekonomi. Selama ini permasalahan yang dihadapi oleh pihak pengambil keputusan atau humas SMK Negeri 2 Mataram dalam seleksi penerima beasiswa adalah waktu yang dibutuhkan sangat lama karena dilakukan secara manual. Karena pihak humas SMK Negeri 2 mataram memilih siswa yang berhak mendapatkan bantuan beasiswa dengan cara verifikasi manual. Cara ini tentunya akan menyebabkan banyak terjadinya salah sasaran dalam pembagiannya, dimana yang dianggap mampu, bisa mendapatkan beasiswa tersebut, sedangkan yang dianggap tidak mampu tidak mendapatkannya. Tidak hanya itu, pihak humas juga kesulitan dalam penentuan penerima beasiswa dikarenakan antar calon penerima memiliki kesamaan nilai setiap kriteria yang digunakan. Adapun kriteria yang digunakan dalam seleksi penerima beasiswa adalah nilai rata-rata, penghasilan orang tua, tanggungan orang tua, jarak tempat tinggal, dan kehadiran. solusi yang ditawarkan pada penelitian ini adalah menggunakan konsep sistem pendukung keputusan dengan kombinasi metode AHP dan TOPSIS untuk seleksi penerima beasiswanya. Metode AHP digunakan untuk pembobotan secara otomatis dan mendapatkan bobot prioritas antar kriteria yang digunakan, untuk minimalisir terjadinya pembobotan secara subyektif. Sedangkan metode TOPSIS digunakan untuk melakukan perangkingan penerima beasiswa dengan cara mengoptimalkan solusi ideal positif dan solusi ideal negatif untuk mendapatkan penerima beasiswa yang tepat dan layak. Tahapan-tahapan dalam pengembangan sistem pendukung keputusan seleksi penerima beasiswa adalah pengumpulan data, perancangan model MADM untuk melihat hubungan antar kriteria dengan alternatifnya, Coding menggunakan Bahasa pemrograman PHP dan Mysql. Tahapan terakhir adalah Pengujian untuk validasi hasilnya dengan perhitungan manual dan sistem. Hasil penelitian yang didapatkan adalah kombinasi metode AHP-TOPSIS mampu dimplementasikan untuk mendapatkan alternatif terbaik sebagai penerima beasiswa. Adapun kesimpulan penelitian ini adalah dengan adanya sistem pendukung keputusan rekomendasi penerima beasiswa tersebut dapat memudahkan dan mempercepat pihak pengambil keputusan (pihak humas) dalam seleksi penerima beasiswa dengan transparan dan okjektif.
\end{abstract}

Kata Kunci: AHP, Topsis, Beasiswa, MADM

Abstract-SMK Negeri 2 Mataram is an educational institution located in the city of Mataram. Every year SMK Negeri 2 Mataram (PR party) selects scholarships for students who have good academic grades but are economically disadvantaged. So far, the problems faced by decision-makers or public relations of SMK Negeri 2 Mataram in selecting scholarship recipients are related to the very long time it takes because it is done manually. Because the selection and verification are done manually, of course, this method will cause a lot of wrong targets in the distribution, where those who are considered capable can get the scholarship, while those who are considered unable do not get it. Not only that, the public relations team also had difficulties in determining the scholarship recipients because the prospective recipients had the same value for each of the criteria used. The criteria used in the selection of scholarship recipients are average scores, parents 'income, parents' dependents, distance from residence to school, and attendance. The solution offered in this study is to use the concept of a decision support system with a combination of AHP and TOPSIS methods for the selection of scholarship recipients. AHP method is used for automatic weighting and to get priority weight among the criteria used, to minimize the subjective weighting. Meanwhile, the TOPSIS method is used to rank scholarship recipients by optimizing positive ideal solutions and negative ideal solutions to get proper and worthy scholarship recipients. The stages in the development of a decision support system for the selection of scholarship recipients are data collection, designing the MADM model to see the relationship between the criteria and the alternatives, coding using the PHP and MySQL programming languages. The last stage is testing to validate the results by manual and system calculations. The results obtained are that the AHP-TOPSIS method combination can be implemented to get the best alternative as a scholarship recipient. The conclusion of this study is that the existence of a decision support system for the recommendation of scholarship recipients can facilitate and accelerate the decision-makers (public relations) in the selection of scholarship recipients transparently and objectively.

Keywords: AHP, Topsis, Scholarship, MADM 


\section{PENDAHULUAN}

Pendidikan merupakan hal yang sangat penting dalam mendukung suatu bangsa untuk menjadi bangsa yang maju. Pendidikan yang baik merupakan cita-cita setiap bangsa untuk mewujudkan kesejahteraan masyarakatnya. Pendidikan sangat erat kaitannya dengan kualitas suatu bangsa. Indonesia saat ini berstatus sebagai negara berkembang, dimana pendidikan masih bermasalah. Disamping sistem yang masih harus diperbaiki dan ditingkatkan lagi, tentunya berkaitan dengan tidak meratanya masyarakatnya yang dapat mengenyam pendidikan yang disebabkan ketidak mampuannya dalam membayar biaya pendididkan. Hal ini tentunya menjadi perhatian pemerintah dalam membantu meyelesaikan permasalahan ini, Salah satunya melalui program beasiswa.

SMK 2 Negeri Mataram merupakan lembaga pedidikan yang terteletak dikota mataram. Setiap tahunnya pihak SMK Negeri 2 Mataram (pihak humas) melakukan seleksi beasiswa bagi siswa yang memiliki nilai akademik bagus tetapi tidak mampu secara ekonomi. SMK 2 Negeri mataram saat ini mendapatkan program bantuan beasiswa dalam menunjang biaya pendidikan para siswanya. Tujuan beasiswa tersebut adalah membantu para siswa kurang mampu tetapi memiliki nilai akademik yang bagus berdasarkan kriteria yang ada.

Sebelumnya SMK Negeri 2 mataram memilih siswa yang berhak mendapat bantuan beasiswa dengan cara verifikasi manual oleh pihak humas. Cara ini tentunya akan menyebabkan banyak terjadinya salah sasaran dalam pembagiannya, dimana yang dianggap mampu, bisa mendapatkan beasiswa tersebut, sedangkan yang dianggap tidak mampu tidak mendapatkannya. Tidak hanya itu, permasalahan lain yang dihadapi oleh pihak pengambil keputusan atau humas SMK Negeri 2 Mataram dalam seleksi penerima beasiswa adalah waktu yang dibutuhkan sangat lama karena dilakukan secara manual. Tidak hanya itu, pihak humas juga kesulitan dalam penentuan penerima beasiswa dikarenakan antar calon penerima memiliki kesamaan nilai setiap kriteria yang digunakan. Dengan pemasalahan tersebut tentunya memerlukan cara penyelesaian yang tepat dan lebih baik dari sebelumnya sehigga beasiswa dapat diterima oleh siswa yang tepat.

Untuk mengatasi permasalahan diatas, solusi yang ditawarkan pada penelitian ini adalah menggunakan konsep sistem Pendukung keputusan. Sistem Pendukung keputusan merupakan sistem berbasis komputer untuk memudahkan pengambil keputusan dalam menyelesaikan permasalahan semi terstruktur. Sistem Pendukung Keputusan digunakan untuk menenetukan pembagian beasiswa dengan cara yang lebih baik. Sistem Pendukung Keputusan tentunya memerlukan kriteria dalam mendukung pengambilan keputusan yang tepat. Kriteria tersebut tentunya ditetepakan oleh pihak sekolah dengan mengikuti peraturan yang ada. Adapun kriteria yang digunakan dalam seleksi penerima beasiswa adalah nilai rata-rata, penghasilan orang tua, tanggungan orang tua, jarak tempat tinggal, dan kehadiran. Adapun data siswa yang ada, kemudian akan diseleksi berdasarkan kriteria yang telah ditentukan sebelumnya sehingga mendapakan hasil berupa siswa yang tepat dalam menerima beasiswa. Penelitian serupa yang sudah dilakukan peneliti sebelumnya dengan menggunakan berbagai macam metode yaitu metode C4.5[1][2], Fuzzy [3], Weighted Product (WP) [4][5], Analytical Hierarchy Process (AHP) [6][7], Fuzzy SAW [8], SAW[9][10], PROMETHEE [11], SAW-WP [12], Neural Network Backpropagation [13], dan Nä̈ve Bayes [14].

Penelitian [15] menggunakan metode SAW dalam seleksi penerimaan beasiswa. Kriteria - kriteria yang digunakan dalam pengambilan keputusan yaitu indeks prestasi akademik (IPK), penghasilan orang tua, prestasi yang pernah diraih, organisasi mahasiswa yang diikuti, dan jumlah tanggungan orang tua. Penelitian [16] dengan metode TOPSIS dalam pemberian beasiswa peserta didik baru, kriteria yang digunakan yaitu jumlah penghasilan orang tua, jumlah tanggungan orang tua, jarak tempat tinggal, nilai rata - rata ujian nasional dan kesanggupan tinggal di asrama. Kriteria tersebut digunakan dalam pengambilan keputusan. Penelitian [13] menggunakan metode Neural Network Backpropagation dalam prediksi penerima besiswa. Dalam penelitian ini kriteria kriteria yang digunakan yaitu nilai IPK, jumlah sks, status, dan pendapatan orang tua. Dengan menggunakan kriteria tersebut dalam penelitian ini didapatkan hasil nilai akurasi rata - rata tertinggi sebesar 99,00\% serta hasil rata - rata nilai error terendah sebesar 0,000101 .

Penelitian [7] menggunakan metode AHP untuk seleksi penerima beasiswa PPS di Universitas Bumigora dengan menggunakan 5 kriteria yaitu penghasilan orang tua, indeks prestasi komulatif(IPK), tanggungan orang tua, semester, dan prestasi. Berdasarkan hasil penelitiannya, metode AHP sangat cocok untuk diterapka dalam penentuan penerima beasiswanya. Penelitian [1] menggunakan metode C.45 untuk seleksi penerima beasiswa PPA dengan menggunakan 125 data dan 5 kriteria. Berdasarkan hasil penelitiannya mendapatkan akurasi 92\%, sensivitas 91.6\%, dan spesifisitasnya 92.3\%. Penelitian [4] menggunakan metode Weighted Product (WP) untuk seleksi penerima beasiswa di Raudlatul Ulum. Ada 5 Kriteria yang digunakan adalah nilai rata-rata, tingkah laku, skstrakurikuler, pendapatan orang tua, dan tanggungan orang tua. Penelitian [10] menggunakan metode SAW untuk seleksi beasiswa kurang mampu berdasarkan 4 kriteria yaitu penghasiln orang tua, pengeluaran orang tua, saudara kandung, dan tanggungan orang tua. Berdasarkan hasil penelitiannya, metode SAW dapat membantu pihak pengambil keputusan (kepala sekolah) untuk memilih calon penerima beasiswa yang tepat.

Berdasarkan kajian penelitian sebelumnya, ada perbedaan yang dilakukan pada penelitian ini yaitu pada penelitian ini melakukan kombinasi metode AHP dan TOPSIS. Metode AHP digunakan untuk pembobotan secara otomatis dan medapatkan bobot prioritas antar kriteria yang digunakan, untuk minimalisir terjadinya pembobotan secara subyektif. Sedangkan metode TOPSIS digunakan untuk melakukan perangkingan penerima beasiswa 
dengan cara mengoptimalkan solusi ideal positif dan solusi ideal negative untuk mendapatkan penerima beasiswa yang tepat dan layak. Dengan adanya sistem Pendukung keputusan rekomendasi penerima beasiswa tersebut dapat memudahkan dan mempercepat pihak pengambil keputusan (pihak humas) dalam seleksi penerima beasiswa dengan transparan dan okjektif.

\section{METODE PENELITIAN}

Penelitian ini terdiri dari 4 tahapan, seperti yang ditunjukkan Gambar 1.

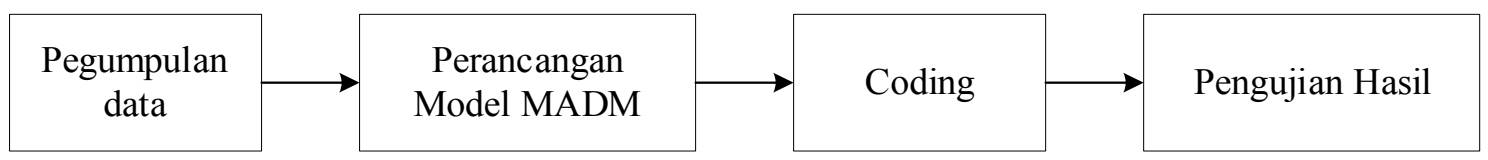

Gambar 1. Tahapan Penelitian

\subsection{Pengumpulan Data}

Data yang digunakan dalam penelitian ini adalah daftar calon siswa penerima beasiswa yang diperoleh dari pihak humas sekolah SMK Negeri 2 Mataram dengan jumlah data sebanyak 20 dan menggunakan 4 kriteria yang masing-masing ditunjukkan pada Tabel 8 dan Tabel 1.

\subsection{Perancangan Model MADM}

Multiple Atribute Decision Making atau MADM adalah sebuah model keputusan dalam pemilihan beberapa alternatif yang memiliki peluang yang sama untuk dipilih berdasarkan banyak kriteria. Perancangan model keputusan MADM digunakan untuk melihat hubungan antar kriteria dengan alternatifnya yang ditunjukkan pada Gambar 2. Dalam penyelesaian model MADM dapat menggunakan beberapa metode yaitu AHP, SAW, WP dan TOPSIS. Dalam penelitian ini model MADM diselesaikan dengan cara mengkombinasikan metode AHP TOPSIS untuk rekomendasi penerima beasiswa siswa SMK Negeri 2 mataram. Metode AHP digunakan untuk pembobotan secara otomatis dan medapatkan bobot prioritas antar kriteria yang digunakan, untuk minimalisir terjadinya pembobotan secara subyektif. Sedangkan metode TOPSIS digunakan untuk melakukan perangkingan penerima beasiswa dengan cara mengoptimalkan solusi ideal positif dan negatif untuk mendapatkan penerima beasiswa yang tepat dan layak.

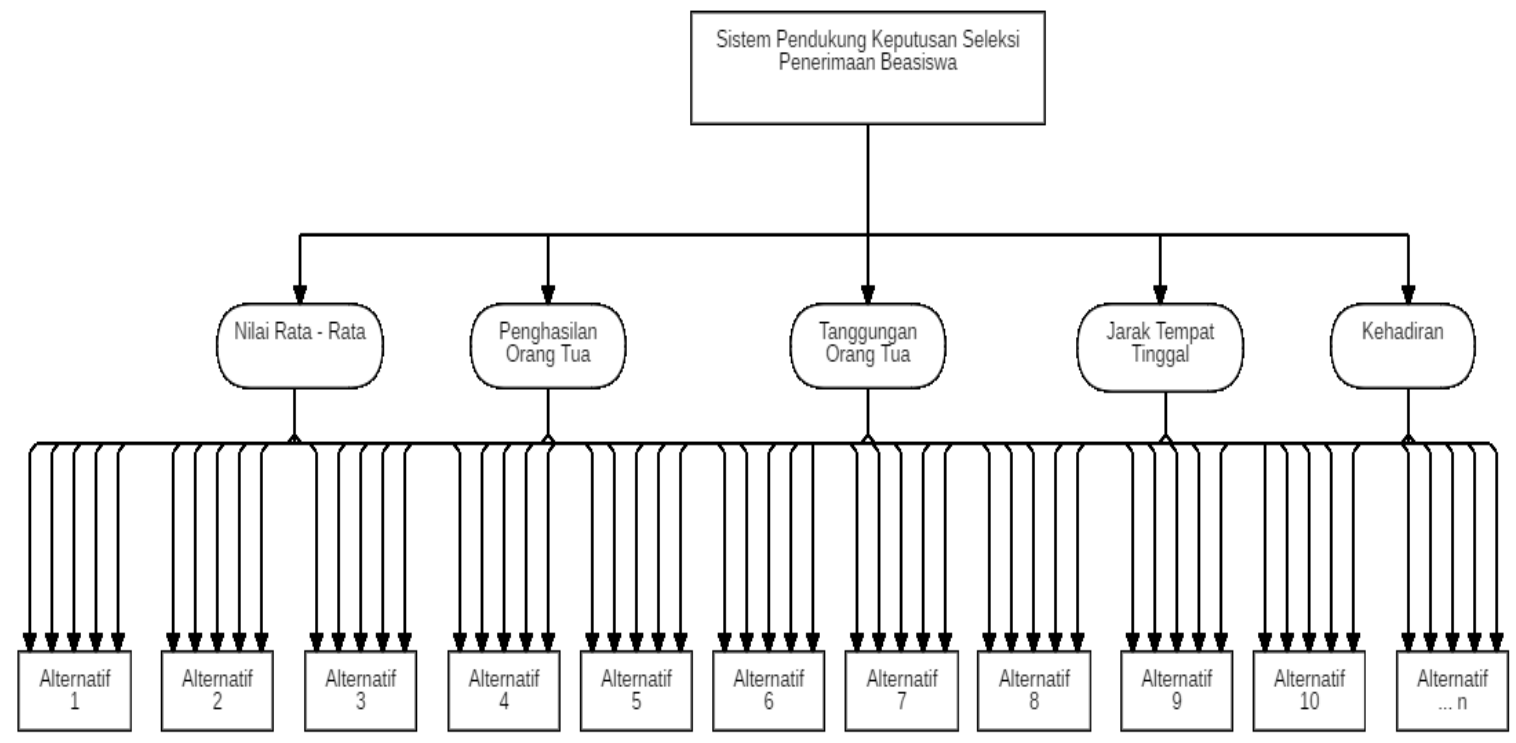

Gambar 2. Pemodelan MADM Sistem Pendukung Keputusan Penerima Beasiswa

Tabel 1. Data Kriteria dan Sifatnya

\begin{tabular}{cclc}
\hline Kode & Kriteria & \multicolumn{1}{c}{ Deskripsi } & $\begin{array}{c}\text { Sifat } \\
\text { Kriteria }\end{array}$ \\
\hline C1 & $\begin{array}{c}\text { Nilai } \\
\text { rata }- \text { rata } \\
\text { Penghasilan } \\
\text { orangtua }\end{array}$ & $\begin{array}{l}\text { nilai rata }- \text { rata raport semester genap. range } \\
\text { nilai } 10-100 .\end{array}$ & $\begin{array}{l}\text { Semakin kecil penghasilan orang tua semakin } \\
\text { bagus }\end{array}$ \\
\hline
\end{tabular}


C3

$\mathrm{C} 4$

C5

\section{Tanggungan} orangtua

Jarak tempat tinggal

Kehadiran
Range penilaian :

1. Diatas Rp. 4.000.000

2. Rp. $3.500 .000-$ Rp. 4.000 .000

3. Rp. $3.000 .000-$ Rp. 3.500 .000

4. Rp. $2.500 .000-$ Rp. 3.000 .000

5. Rp. $2.000 .000-$ Rp. 2.500 .000

6. Rp. $1.500 .000-$ Rp. 2.000 .000

Cost

7. Rp. $1.000 .000-$ Rp. 1.500 .000

8. Rp. 500.000 - Rp. 1.000 .000

9. Kurang dari Rp. 500.000

10. Tidak Berpenghasilan

Semakin banyak tanggungan orang tua semakin bagus

Benefit

Semakin jauh jarak tempat tinggal dari sekolah, semakin bagus.

Range penilian pada kriteria ini, yaitu :

1. Kurang dari $1 \mathrm{Km}$

2. $1 \mathrm{Km}-1,5 \mathrm{Km}$

3. $1,5 \mathrm{Km}-2 \mathrm{Km}$

4. $2 \mathrm{Km}-2,5 \mathrm{Km}$

5. $2,5 \mathrm{Km}-3 \mathrm{Km}$

6. $3 \mathrm{Km}-3,5 \mathrm{Km}$

7. $3,5 \mathrm{Km}-4 \mathrm{Km}$

8. Diatas $4 \mathrm{Km}$

Benefit

Semakin banyak kehadirannya, semakin bagus. Range peniliaian:

1. Kurang rajin : dengan jumlah tanpa keterangan diatas 5

2. Cukup rajin : dengan jumlah tanpa keterangan diatas 2 dan dibawah 5

Benefit

3. Rajin : dengan jumlah tanpa keterangan 1

4. Sangat rajin : dengan jumlah tanpa keterangan 0 atau tidak ada

\subsubsection{Metode MADM}

Dalam penelitian ini metode yang digunakan dalam penyelesaian permasalahan MADM adalah kombinnasi metode AHP dan Topsis. Metode AHP digunakan untuk pembobotan secara otomatis dan medapatkan bobot prioritas antar kriteria yang digunakan, untuk minimalisir terjadinya pembobotan secara subyektif. Sedangkan metode TOPSIS digunakan untuk melakukan perangkingan penerima beasiswa dengan cara mengoptimalkan solusi ideal positif dan negatif untuk mendapatkan penerima beasiswa yang tepat dan layak. Adapun tahapan perhitungan kombinasi metode AHP dan TOPSIS seperti berikut:

a. Tahapan Pembobotan Kriteria Seleksis Beasiswa Menggunakan Metode AHP

1. Membuat Struktur Hirarki Masalah

Pada bagian ini membuat struktur hirarki masalah untuk menggambarkan tujuan, kriteria, dan alterative yang digunakan.

2. Menentukan Tingkat Kepentingan Antar Kriteria

Tahapan pertama dalam perhitungan metode AHP adalah penentuan tingkat kepentingan antar kriteria yang digunakan untuk membuat matriks perbandingan berpasangannya. Adapun tingkat kepentingan antar kriterianya ditunjukkan pada Tabel 2.

Tabel 2. Tingkat kepentingan Antar Kriteria

\begin{tabular}{cc}
\hline Nilai & Keterangan \\
\hline 9 & Mutlak lebih diutamakan \\
7 & Sangat lebih diutamakan \\
5 & Lebih diutamakan \\
\hline
\end{tabular}


$3 \quad$ Cukup diutamakan

1 Sama - sama diuatamakan

3. Membuat Matriks Perbandingan Berpasangan Kriteria

Pada bagian ini membuat matriks perbandingan berpasangan kriteria berdasarkan tingkat kepentingan antar kriteria yang sudah ditentukan sebelumnya.

4. Pengujian Konsistensi Bobot

Bobot yang dihasilkan akan dilakukan uji konsistensinya, jika konsisten maka bobotnya dapat digunakan tetapi jika tidak konsisten prosesnya kembali untuk menentukan tingkat kepentingan antar kriterianya. Adapun formulasi yang digunakan untuk melakukan uji konsistensi ditunjukkan pada (1), (2), dan (3).

$$
\begin{aligned}
& t=\frac{1}{n} \sum_{i=1}^{n}\left(\frac{\text { elemen } k e-i \text { pada }(\mathrm{A})\left(\mathrm{W}^{T}\right)}{\text { elemen } k e-i \text { pada }\left(\mathrm{W}^{T}\right)}\right) \\
& C I=\frac{t-n}{n-1} \\
& C R=\frac{C I}{R I_{n}}
\end{aligned}
$$

Jika $\mathrm{C} 1=0$, bobotnya konsisten

Jika CR $<0,1$, bobotnya cukup konsisten

Jika $\mathrm{CR}>0$, bobotnya tidak konsisten

b. Tahapan Perangkingan Seleksi Penerima Beasiswa Menggunakan Metode TOPSIS

1. Membuat Matriks Keputusan

2. Melakukan Normalisasi Matriks Keputusan

Membuat matrik keputusan ternormalisasi dengan persamaan (4).

$$
r_{i j}=\frac{X_{i j}}{\sqrt{\sum_{i=1}^{m} X_{i j}^{2}}}
$$

3. Melakukan Normalisasi Terbobot pada Matriks Keputusan Ternormalisasi

Membuat matriks keputusan ternormalisasi terbobot dengan persamaan (5).

$$
y_{i j}=W_{i} * r_{i j}
$$

4. Menentukan Solusi Ideal Positif dan Negatif

Penentuan solusi ideal positif dan negatif ditentukan berdasarkan matriks keputusan ternormalisasi terbobot menggunakan persamaan (6).

$$
\begin{aligned}
& A^{+}=\left(y_{1}^{+}, y_{2}^{+}, \ldots . . y_{n}^{+}\right) \\
& A^{-}=\left(y_{1}^{-}, y_{2}^{-}, \ldots . . y_{n}^{-}\right)
\end{aligned}
$$

5. Menentukan jarak antara alternatif dengan solusi ideal positif dan negative

Dalam penentuan jarak antara alternatif dengan solusi ideal positif dan negative dapat menggunakan persamaan (7) dan (8)

$$
\begin{aligned}
& D_{i}^{+}=\sqrt{\sum_{j=1}^{n}\left(y_{i}^{+}-y_{i j}\right)^{2}} \\
& D_{i}^{-}=\sqrt{\sum_{j=1}^{n}\left(y_{i j}-y_{i}^{-}\right)^{2}}
\end{aligned}
$$

6. Menentukan nilai preferensi untuk setiap alternatif

Penentuan nilai preferensi untuk setiap alternatif berdasarkan persamaan (9).

$$
V_{i}=\frac{D_{i}^{-}}{D_{i}^{-}+D_{i}^{+}}
$$


Untuk mempermudah memahami tahapan seleksi penerima beasiswa SMK 2 Negeri Mataram dengan metode AHP dan Topsis, maka dibuatkan alurnya dalam bentuk flowchart yang ditunjukkan pada Gambar 3.
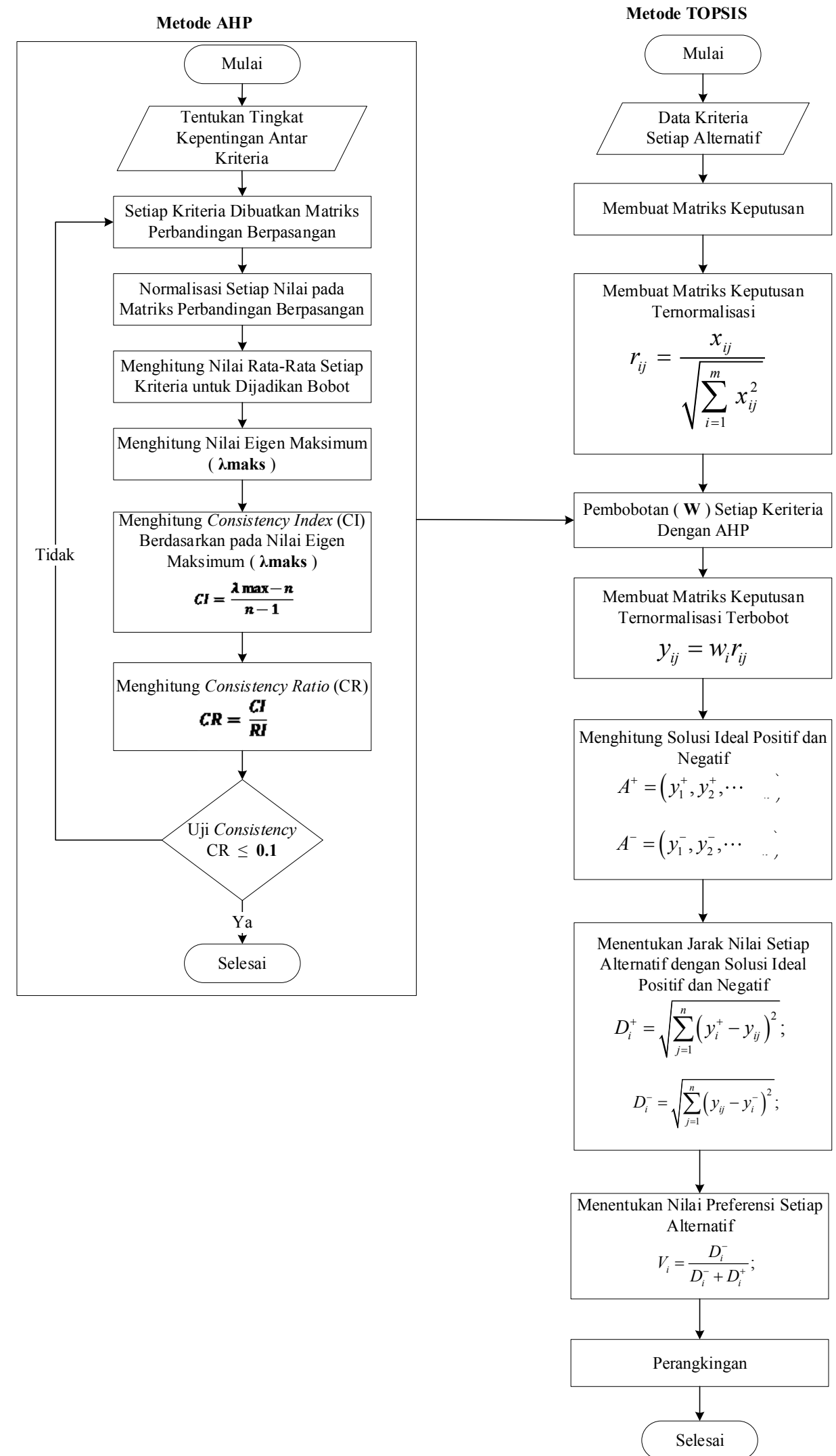

Gambar 3. Flowchart Metode AHP-TOPSIS

Pada Gambar 3 merupakan alur penyelesain menggunakan kombinasi metode AHP dan TOPSIS. Proses pertama dilakukan menggunakan metode AHP sebagai tahapan dalam menenetukan bobot secara otomatis dan 
medapatkan bobot prioritas antar kriteria yang digunakan, untuk minimalisir terjadinya pembobotan secara subyektif. Setelah bobot didapatkan kemudian dilakukan proses perengkingan menggunakan metode TOPSIS. Prinsip dari metode TOPSIS adalah menentukan alternatif, kemudian menentukannya dengan jarak terdekat dari solusi ideal positif dan juga jarak terpanjang dari solusi ideal negatif. Untuk hasil yang terbaik adalah alternatif yang memiliki jarak terdekat dari solusi ideal positif. Setelah proses tersebut, kemudian dilakukan penentuan nilai preferensi dan pada akhirnya dilakukan proses perengkingan untuk mengurutkan hasilnya dari nilai terbaik.

\subsection{Coding}

Pada tahapan ini dilakukan pengembangan sistem pendukung keputusan seleksi beasiswa SMK Negeri 2 Mataram berbasis web menggunakan Bahasa pemrograman PHP dan basis data Mysql.

\subsection{Pengujian}

Pada tahapan ini dilakukan pengujian validasi hasil perangkingan alternatif penerima beasiswa dengan metode AHP dan Topsis menggunakan perhitungan manual dengan perhitungan sistem.

\section{HASIL DAN PEMBAHASAN}

Pada bagian ini menjelaskan tahapan-tahapan penentuan siswa yang berhak menerima beasiswa dengan kombinasi metode AHP dan TOPSIS secara manual dan juga menggunakan aplikasi yang dibangun menggunakan Bahasa pemrograman PHP dan Mysql sebagai basis datanya.

\subsection{Implementasi Metode AHP dan Topsis}

a. Tahapan Pembobotan Menggunakan Metode AHP

1. Menentukan Tingkat Kepentingan Antar Kriteria

Tahapan pertama dalam perhitungan metode AHP adalah penentuan tingkat kepentingan antar kriteria yang digunakan untuk membuat matriks perbandingan berpasangannya. Adapun tingkat kepentingan antar kriteria pada penelitian ini yaitu:

a. Kriteria nilai rata - rata (C1) cukup penting [3] dibandingkan kriteria penghasilan orang tua (C2) dan tanggungan orang tua (C3).

b. Kriteria nilai rata - rata $(\mathrm{C} 1)$ lebih penting [5] dibandingkan kriteria jarak tempat tinggal (C4) dan kehadiran (C5).

c. Kriteria penghasilan orang tua (C2) sama penting [1] dibandingkan kriteria tanggungan orang tua $(\mathrm{C} 3)$

d. Kriteria penghasilan orang tua $(\mathrm{C} 2)$ cukup penting [3] dibandingkan kriteria jarak tempat tinggal (C4) dan kehadiran (C5).

e. Kriteria tanggungan orang tua (C3) cukup penting [3] dibandingkan kriteria jarak tempat tinggal (C4) dan kehadiran (C5).

f. Kriteria kriteria jarak tempat tinggal (C4) sama penting [1] dibandingkan kriteria kehadiran (C5).

2. Membuat Matriks Perbandingan Berpasangan Kriterianya

Pembuatan matriks perbandingan berpasangan antar kriterianya berdasarkan nilai tingkat kepentingan yang sudah didefinisikan sebelumnya. Adapun matriks keputusan perbandingan kriterianya ditunjukkan pada Tabel 3 dan Tabel 4.

Tabel 3. Perbandingan Berpasangan Antar Kriteria

\begin{tabular}{cccccc}
\hline & C1 & C2 & C3 & C4 & C5 \\
\hline C1 & 1 & 3 & 3 & 5 & 5 \\
C2 & $1 / 3$ & 1 & 1 & 3 & 3 \\
C3 & $1 / 3$ & 1 & 1 & 3 & 3 \\
C4 & $1 / 5$ & $1 / 3$ & $1 / 3$ & 1 & 1 \\
C5 & $1 / 5$ & $1 / 3$ & $1 / 3$ & 1 & 1 \\
\hline
\end{tabular}

Tabel 4. Hasil Perbandingan Berpasangan Antar Kriteria

\begin{tabular}{cccccc}
\hline & C1 & C2 & C3 & C4 & C5 \\
\hline C1 & 1 & 3 & 3 & 5 & 5 \\
C2 & 0,33 & 1 & 1 & 3 & 3 \\
C3 & 0,33 & 1 & 1 & 3 & 3 \\
C4 & 0,2 & 0,33 & 0,33 & 1 & 1 \\
C5 & 0,2 & 0,33 & 0,33 & 1 & 1 \\
\hline
\end{tabular}




$\begin{array}{llllll}\text { Total } & 2,06 & 5,66 & 5,66 & 13 & 13\end{array}$

3. Melakukan normalisasi pada setiap nilai matriks berpasangan dengan membagi setiap nilai pada kolom dengan nilai total masing - masing kolom.

Normalisasi nilai matriks berpasangan pada Tabel 3 dilakukan untuk menjadikan rentang nilainya 1 sampai 0 . Adapun hasil normalisasi perbandingan berpasangan ditunjukkan pada Tabel 5.

Tabel 5. Hasil Normalisasi Perbandingan Berpasangan Antar Kriteria

\begin{tabular}{rccccc}
\hline & $\mathrm{C} 1$ & $\mathrm{C} 2$ & $\mathrm{C} 3$ & $\mathrm{C} 4$ & $\mathrm{C} 5$ \\
\hline $\mathrm{C} 1$ & 0,4838 & 0,5294 & 0,5294 & 0,3846 & 0,3846 \\
$\mathrm{C} 2$ & 0,1612 & 0,1764 & 0,1764 & 0,2307 & 0,2307 \\
$\mathrm{C} 3$ & 0,1612 & 0,1764 & 0,1764 & 0,2307 & 0,2307 \\
$\mathrm{C} 4$ & 0,0967 & 0,0588 & 0,0588 & 0,0769 & 0,0769 \\
$\mathrm{C} 5$ & 0,0967 & 0,0588 & 0,0588 & 0,0769 & 0,0769 \\
Total & $\mathbf{1}$ & $\mathbf{1}$ & $\mathbf{1}$ & $\mathbf{1}$ & $\mathbf{1}$ \\
\hline
\end{tabular}

4. Menentukan nilai rata - rata matriks kriteria dengan cara menjumlahkan seluruh nilai perbaris dan dibagi dengan jumlah kriteria yang ada.

Hasil nilai rata - ratanya ditunjukkan pada Tabel 6

Tabel 6. Hasil Bobot Setiap Kriteria

\begin{tabular}{ccccccc}
\hline & $\mathrm{C} 1$ & $\mathrm{C} 2$ & $\mathrm{C} 3$ & $\mathrm{C} 4$ & $\mathrm{C} 5$ & Rata - Rata \\
\hline C1 & 0,4838 & 0,5294 & 0,5294 & 0,3846 & 0,3846 & $\mathbf{0 , 4 6 2 4}$ \\
C2 & 0,1612 & 0,1764 & 0,1764 & 0,2307 & 0,2307 & $\mathbf{0 , 1 9 5 1}$ \\
C3 & 0,1612 & 0,1764 & 0,1764 & 0,2307 & 0,2307 & $\mathbf{0 , 1 9 5 1}$ \\
C4 & 0,0967 & 0,0588 & 0,0588 & 0,0769 & 0,0769 & $\mathbf{0 , 0 7 3 6}$ \\
C5 & 0,0967 & 0,0588 & 0,0588 & 0,0769 & 0,0769 & $\mathbf{0 , 0 7 3 6}$ \\
\hline
\end{tabular}

Nilai rata - rata yang ditunjukkan pada Tabel 6 digunakan sebagai bobotnya untuk perhitungan pada metode Topsis dalam pembuatan normalisasi terbobotnya. Nilai bobot yang dihasilkan oleh metode AHP tidak bisa digunakan secara langsung, tetapi harus terlebih dahulu uji konsistensinya. Adapun daftar bobot yang didapatkan dari metode AHPnya adalah $\mathbf{W}=[\mathbf{0 . 4 6 2 4}, \mathbf{0 . 1 9 5 1 , 0 . 1 9 5 1}$, 0.0736, 0.0736]

5. Mencari nilai Lamda masksimum ( $\lambda$ maks ) kemudian akan digunakan untuk mengukur konsistensi

Untuk mendapatkan nilai $\lambda$ maks, dapat dihitung dengan konsep perkalian matriks antara matriks perbandingan berpasangan pada Tabel 4 dan nilai bobot transpose. Adapun proses perhitungannya ditunjukkan pada Gambar 4 dan hasil nilai lamda maksimumnya ditunjukkan pada Tabel 7.

$$
\left(\begin{array}{ccccc}
1 & 3 & 3 & 5 & 5 \\
0,33 & 1 & 1 & 3 & 3 \\
0,33 & 1 & 1 & 3 & 3 \\
0,2 & 0,33 & 0,33 & 1 & 1 \\
0,2 & 0,33 & 0,33 & 1 & 1
\end{array}\right)\left(\begin{array}{l}
0,4624 \\
0,1951 \\
0,1951 \\
0,0736 \\
0,0736
\end{array}\right)=\left(\begin{array}{l}
2,3698 \\
0,9863 \\
0,9863 \\
0,3698 \\
0,2962
\end{array}\right)
$$

Gambar 4. Proses Perhitungan $\lambda$ maks

Tabel 7. Nilai Lamda Maskimum ( $\lambda$ maks)

\begin{tabular}{cccccccc}
\hline & C1 & C2 & C3 & C4 & C5 & W & $\begin{array}{c}\text { Lamda } \\
\text { Maks }\end{array}$ \\
\hline C1 & 0,4838 & 0,5294 & 0,5294 & 0,3846 & 0,3846 & $\mathbf{0 , 4 6 2 4}$ & $\mathbf{2 , 3 6 9 8}$ \\
C2 & 0,1612 & 0,1764 & 0,1764 & 0,2307 & 0,2307 & $\mathbf{0 , 1 9 5 1}$ & $\mathbf{0 , 9 8 6 3}$ \\
C3 & 0,1612 & 0,1764 & 0,1764 & 0,2307 & 0,2307 & $\mathbf{0 , 1 9 5 1}$ & $\mathbf{0 , 9 8 6 3}$ \\
C4 & 0,0967 & 0,0588 & 0,0588 & 0,0769 & 0,0769 & $\mathbf{0 , 0 7 3 6}$ & $\mathbf{0 , 3 6 9 8}$ \\
\hline
\end{tabular}


C 5

6. Mencari nilai $\mathrm{t}$

Nilai t didapat dengan setiap sel nilai $\lambda$ max dibagi dengan setiap sel nilai rata - rata dan ditambahkan kemudian dibagi dengan jumlah data kriteria.

$$
t=\frac{1}{5} *\left(\left(\frac{2.3698}{0.4624}\right)+\left(\frac{0.9863}{0.1951}\right)+\left(\frac{0.9863}{0.1951}\right)+\left(\frac{0.3698}{0.0736}\right)+\left(\frac{0.2962}{0.1951}\right)\right)=\mathbf{5 , 0 5 4 5}
$$

7. Menghitung Consistency Index (CI)

Untuk menghitung consistency index persamaan (2).

8. Menghitung Consistency Ratio (CR)

$$
C I=\frac{5,0545-5}{5-1}=\mathbf{0 , 0 1 3 6}
$$

Perhitungan nilai consistency ratio dengan cara nilai CI dibagi dengan nilai Random Index (RI). Pada penelitian ini menggunakan 5 kriteria, sehinggan nilai RI adalah 1,12. Adapun proses perhitungan CI menggunakan persamaan (3).

$$
C R=\frac{0,0136}{1,12}=\mathbf{0 , 0 1 2 2}
$$

Berdasarkan nilai CR yang dihasilkan $(\mathbf{0 , 0 1 2 2})<0,1$ maka bobot setiap kriteria dapat dikatakan konsisten. Sehingga bobot yang didapatkan menggunakan metode AHP dapat digunakan.

b. Tahapan Perangkingan Calon Penerima Beasiswa Menggunakan Metode Topsis

1. Pembuatan data alternatif beserta kriterianya dalam bentuk matriks keputusan.

Tahapan pertama adalah membuat matriks keputusan berdasarkan data alternatif beserta kriteria calon penerima beasiswa siswa SMK Negeri 2 Mataram yang didapatkan dari pihak humasnya. Adapun matriks keputusannya ditunjukkan pada Tabel 8.

Tabel 8. Matriks Keputusan

\begin{tabular}{lccccc}
\hline \multicolumn{1}{c}{ Alternatif } & \multicolumn{5}{c}{ Kriteria } \\
\cline { 2 - 6 } & $\mathrm{C} 1$ & $\mathrm{C} 2$ & $\mathrm{C} 3$ & $\mathrm{C} 4$ & $\mathrm{C} 5$ \\
\hline Aditya Rahmadi & 86 & 3 & 3 & 8 & 1 \\
Alma Ariana & 87 & 8 & 2 & 5 & 4 \\
Anisa Ulansari & 79 & 9 & 3 & 7 & 2 \\
Arya Budiman & 85 & 3 & 5 & 4 & 4 \\
Ayu Diastini & 88 & 6 & 2 & 8 & 1 \\
Baiq Ayu & 82 & 3 & 1 & 6 & 3 \\
Cecar Nurcahyadi & 82 & 3 & 5 & 8 & 4 \\
Eka Sabrina & 83 & 6 & 3 & 7 & 4 \\
Leli Dwi Pratiwi & 86 & 1 & 1 & 3 & 4 \\
Hofifah & 86 & 3 & 2 & 6 & 3 \\
Yusril Ihza Islami & 81 & 4 & 2 & 4 & 2 \\
Yulanda Debora & 86 & 9 & 5 & 6 & 3 \\
Yudha Krisnadi & 82 & 3 & 4 & 6 & 3 \\
Wina Wulandari & 79 & 6 & 3 & 8 & 3 \\
Risma Yuninda & 80 & 4 & 1 & 5 & 4 \\
Regar Febryan Adha & 89 & 10 & 3 & 6 & 4 \\
Norma Noviani & 84 & 6 & 2 & 4 & 4 \\
Muhammad Riyandana Putra & 81 & 6 & 1 & 6 & 4 \\
Muchamad Ruchyat Cahyana & 85 & 6 & 5 & 4 & 2 \\
Mona Febrianti & 83 & 5 & 1 & 8 & 3 \\
\hline
\end{tabular}

2. Pembuatan matriks keputusan ternormalisasi

Hasil normalisasi matriks keputusannya ditunjukkan pada Tabel 9.

Tabel 9. Hasil Matriks Keputusan Ternormalisasi

\begin{tabular}{lccccc}
\hline \multicolumn{1}{c}{ Alternatif } & \multicolumn{5}{c}{ Kriteria } \\
\cline { 2 - 6 } & $\mathrm{C} 1$ & $\mathrm{C} 2$ & $\mathrm{C} 3$ & $\mathrm{C} 4$ & $\mathrm{C} 5$ \\
\hline Aditya Rahmadi & 0.2296 & 0.1173 & 0.2200 & 0.2908 & 0.0687 \\
Alma Ariana & 0.2323 & 0.3128 & 0.1466 & 0.1817 & 0.2747 \\
Anisa Ulansari & 0.2109 & 0.3519 & 0.2200 & 0.2544 & 0.1374 \\
\hline
\end{tabular}




\begin{tabular}{llllll} 
Arya Budiman & 0.2269 & 0.1173 & 0.3666 & 0.1454 & 0.2747 \\
Ayu Diastini & 0.2350 & 0.2346 & 0.1466 & 0.2908 & 0.0687 \\
Baiq Ayu & 0.2189 & 0.1173 & 0.0733 & 0.2181 & 0.2060 \\
Cecar Nurcahyadi & 0.2189 & 0.1173 & 0.3666 & 0.2908 & 0.2747 \\
Eka Sabrina & 0.2216 & 0.2346 & 0.2200 & 0.2544 & 0.2747 \\
Leli Dwi Pratiwi & 0.2296 & 0.0391 & 0.0733 & 0.1090 & 0.2747 \\
Hofifah & 0.2296 & 0.1173 & 0.1466 & 0.2181 & 0.2060 \\
Yusril Ihza Islami & 0.2163 & 0.1564 & 0.1466 & 0.1454 & 0.1374 \\
Yulanda Debora & 0.2296 & 0.3519 & 0.3666 & 0.2181 & 0.2060 \\
Yudha Krisnadi & 0.2189 & 0.1173 & 0.2933 & 0.2181 & 0.2060 \\
Wina Wulandari & 0.2109 & 0.2346 & 0.2200 & 0.2908 & 0.2060 \\
Risma Yuninda & 0.2136 & 0.1564 & 0.0733 & 0.1817 & 0.2747 \\
Regar Febryan Adha & 0.2376 & 0.3910 & 0.2200 & 0.2181 & 0.2747 \\
Norma Noviani & 0.2243 & 0.2346 & 0.1466 & 0.1454 & 0.2747 \\
Muhammad Riyandana Putra & 0.2163 & 0.2346 & 0.0733 & 0.2181 & 0.2747 \\
Muchamad Ruchyat Cahyana & 0.2269 & 0.2346 & 0.3666 & 0.1454 & 0.1374 \\
Mona Febrianti & 0.2216 & 0.1955 & 0.0733 & 0.2908 & 0.2060 \\
\hline
\end{tabular}

3. Membuat matriks ternormalisasi terbobot dengan menggunakan bobot prioritas yang didapat dengan metode AHP

Perhitungan matiks ternormalisasi terbobot dengan cara melakukan perkalian antara nilai setiap alternatif pada matriks keputusan ternormalisasi dikalikan dengan nilai bobot yang dihasilkan dari metode AHP.

Adapun hasil matriks keputusan ternormalisasi terbobot ditunjukkan pada Tabel 10.

Tabel 10. Hasil Matriks Keputusan Ternormalisasi Terbobot

\begin{tabular}{lccccc}
\hline \multicolumn{1}{c}{ Alternatif } & \multicolumn{5}{c}{ Kriteria } \\
\cline { 2 - 6 } & $\mathrm{C} 1$ & $\mathrm{C} 2$ & $\mathrm{C} 3$ & $\mathrm{C} 4$ & $\mathrm{C} 5$ \\
\hline Aditya Rahmadi & 0.1062 & 0.0229 & 0.0429 & 0.0214 & 0.0051 \\
Alma Ariana & 0.1074 & 0.0610 & 0.0286 & 0.0134 & 0.0202 \\
Anisa Ulansari & 0.0975 & 0.0687 & 0.0429 & 0.0187 & 0.0101 \\
Arya Budiman & 0.1049 & 0.0229 & 0.0715 & 0.0107 & 0.0202 \\
Ayu Diastini & 0.1087 & 0.0458 & 0.0286 & 0.0214 & 0.0051 \\
Baiq Ayu & 0.1012 & 0.0229 & 0.0143 & 0.0161 & 0.0152 \\
Cecar Nurcahyadi & 0.1012 & 0.0229 & 0.0715 & 0.0214 & 0.0202 \\
Eka Sabrina & 0.1025 & 0.0458 & 0.0429 & 0.0187 & 0.0202 \\
Leli Dwi Pratiwi & 0.1062 & 0.0076 & 0.0143 & 0.0080 & 0.0202 \\
Hofifah & 0.1062 & 0.0229 & 0.0286 & 0.0161 & 0.0152 \\
Yusril Ihza Islami & 0.1000 & 0.0305 & 0.0286 & 0.0107 & 0.0101 \\
Yulanda Debora & 0.1062 & 0.0687 & 0.0715 & 0.0161 & 0.0152 \\
Yudha Krisnadi & 0.1012 & 0.0229 & 0.0572 & 0.0161 & 0.0152 \\
Wina Wulandari & 0.0975 & 0.0458 & 0.0429 & 0.0214 & 0.0152 \\
Risma Yuninda & 0.0988 & 0.0305 & 0.0143 & 0.0134 & 0.0202 \\
Regar Febryan Adha & 0.1099 & 0.0763 & 0.0429 & 0.0161 & 0.0202 \\
Norma Noviani & 0.1037 & 0.0458 & 0.0286 & 0.0107 & 0.0202 \\
Muhammad Riyandana Putra & 0.1000 & 0.0458 & 0.0143 & 0.0161 & 0.0202 \\
Muchamad Ruchyat Cahyana & 0.1049 & 0.0458 & 0.0715 & 0.0107 & 0.0101 \\
Mona Febrianti & 0.1025 & 0.0382 & 0.0143 & 0.0214 & 0.0152 \\
\hline
\end{tabular}

4. Menentukan matriks solusi ideal positif dan solusi ideal negatif.

Nilai solusi ideal positif dan solusi ideal negatif pada masing - masing kriterianya, ditunjukkan pada Tabel 11.

Tabel 11. Matriks Solusi Ideal Positif dan Negatif

\begin{tabular}{cccccc}
\hline & C1 & C2 & C3 & C4 & C5 \\
\hline A+ & 0,1099 & 0,0076 & 0,0715 & 0,0214 & 0,0202 \\
A- & 0,0975 & 0,0763 & 0,0143 & 0,0080 & 0,0051 \\
\hline
\end{tabular}

5. Menentukan jarak solusi ideal positif dan solusi ideal negatif. 
Tabel 12. Hasil Nilai Jarak Solusi Ideal Positif dan Negatif

\begin{tabular}{lcc}
\hline \multicolumn{1}{c}{ Alternatif } & \multicolumn{2}{c}{ Jarak Solusi Ideal } \\
\cline { 2 - 3 } & $\mathrm{D}+$ & $\mathrm{D}-$ \\
\hline Aditya Rahmadi & 0.0329 & 0.0627 \\
Alma Ariana & 0.0690 & 0.0240 \\
Anisa Ulansari & 0.0687 & 0.0315 \\
Arya Budiman & 0.0193 & 0.0789 \\
Ayu Diastini & 0.0577 & 0.0379 \\
Baiq Ayu & 0.0601 & 0.0542 \\
Cecar Nurcahyadi & 0.0175 & 0.0797 \\
Eka Sabrina & 0.0483 & 0.0437 \\
Leli Dwi Pratiwi & 0.0589 & 0.0694 \\
Hofifah & 0.0460 & 0.0566 \\
Yusril Ihza Islami & 0.0509 & 0.0481 \\
Yulanda Debora & 0.0614 & 0.0590 \\
Yudha Krisnadi & 0.0233 & 0.0692 \\
Wina Wulandari & 0.0493 & 0.0440 \\
Risma Yuninda & 0.0631 & 0.0463 \\
Regar Febryan Adha & 0.0746 & 0.0324 \\
Norma Noviani & 0.0587 & 0.0346 \\
Muhammad Riyandana Putra & 0.0697 & 0.0319 \\
Muchamad Ruchyat Cahyana & 0.0400 & 0.0654 \\
Mona Febrianti & 0.0653 & 0.0408 \\
\hline
\end{tabular}

6. Menentukan nilai preferensi

Tabel 13. Nilai Preferensi

\begin{tabular}{lc}
\hline \multicolumn{1}{c}{ Alternatif } & Hasil Akhir \\
\hline Aditya Rahmadi & 0.6559 \\
Alma Ariana & 0.2578 \\
Anisa Ulansari & 0.3145 \\
Arya Budiman & 0.8036 \\
Ayu Diastini & 0.3968 \\
Baiq Ayu & 0.4743 \\
Cecar Nurcahyadi & $\mathbf{0 . 8 1 9 7}$ \\
Eka Sabrina & 0.4748 \\
Leli Dwi Pratiwi & 0.5411 \\
Hofifah & 0.5516 \\
Yusril Ihza Islami & 0.4861 \\
Yulanda Debora & 0.4901 \\
Yudha Krisnadi & 0.7482 \\
Wina Wulandari & 0.4718 \\
Risma Yuninda & 0.4233 \\
Regar Febryan Adha & 0.3029 \\
Norma Noviani & 0.3707 \\
Muhammad Riyandana Putra & 0.3139 \\
Muchamad Ruchyat Cahyana & 0.6202 \\
Mona Febrianti & 0.3847 \\
\hline
\end{tabular}

7. Perangkingan

Hasil akhir yang didapatkan menggunakan metode Topsis, dilakukan perangkingan berdasarkan nilai terbesar dari tiap-tiap calon penerima beasiswa atau alternatif. Hasil perangkingannya ditunjukkan pada Tabel 14.

Tabel 14. Hasil Perangkingan

\begin{tabular}{lll}
\hline No. & \multicolumn{1}{c}{ Alternatif } & Hasil Akhir \\
\hline 1. & Cecar Nurcahyadi & $\mathbf{0 . 8 1 9 7}$ \\
2. & Arya Budiman & $\mathbf{0 . 8 0 3 6}$ \\
3. & Yudha Krisnadi & $\mathbf{0 . 7 4 8 2}$ \\
\hline
\end{tabular}




\begin{tabular}{lll} 
4. & Aditya Rahmadi & 0.6559 \\
5. & Muchamad Ruchyat Cahyana & 0.6202 \\
6. & Hofifah & 0.5516 \\
7. & Leli Dwi Pratiwi & 0.5411 \\
8. & Yulanda Debora & 0.4901 \\
9. & Yusril Ihza Islami & 0.4861 \\
10. & Eka Sabrina & 0.4748 \\
11. & Baiq Ayu & 0.4743 \\
12. & Wina Wulandari & 0.4718 \\
13. & Risma Yuninda & 0.4233 \\
14. & Ayu Diastini & 0.3968 \\
15. & Mona Febrianti & 0.3847 \\
16. & Norma Noviani & 0.3707 \\
17. & Anisa Ulansari & 0.3145 \\
18. & Muhammad Riyandana Putra & 0.3139 \\
19. & Regar Febryan Adha & 0.3029 \\
20. & Alma Ariana & 0.2578 \\
\hline
\end{tabular}

Sedangkan hasil perhitungan penerima beasiswa berbasis AHP-TOPSIS menggunakan sistem, ditunjukkan pada Gambar 5.
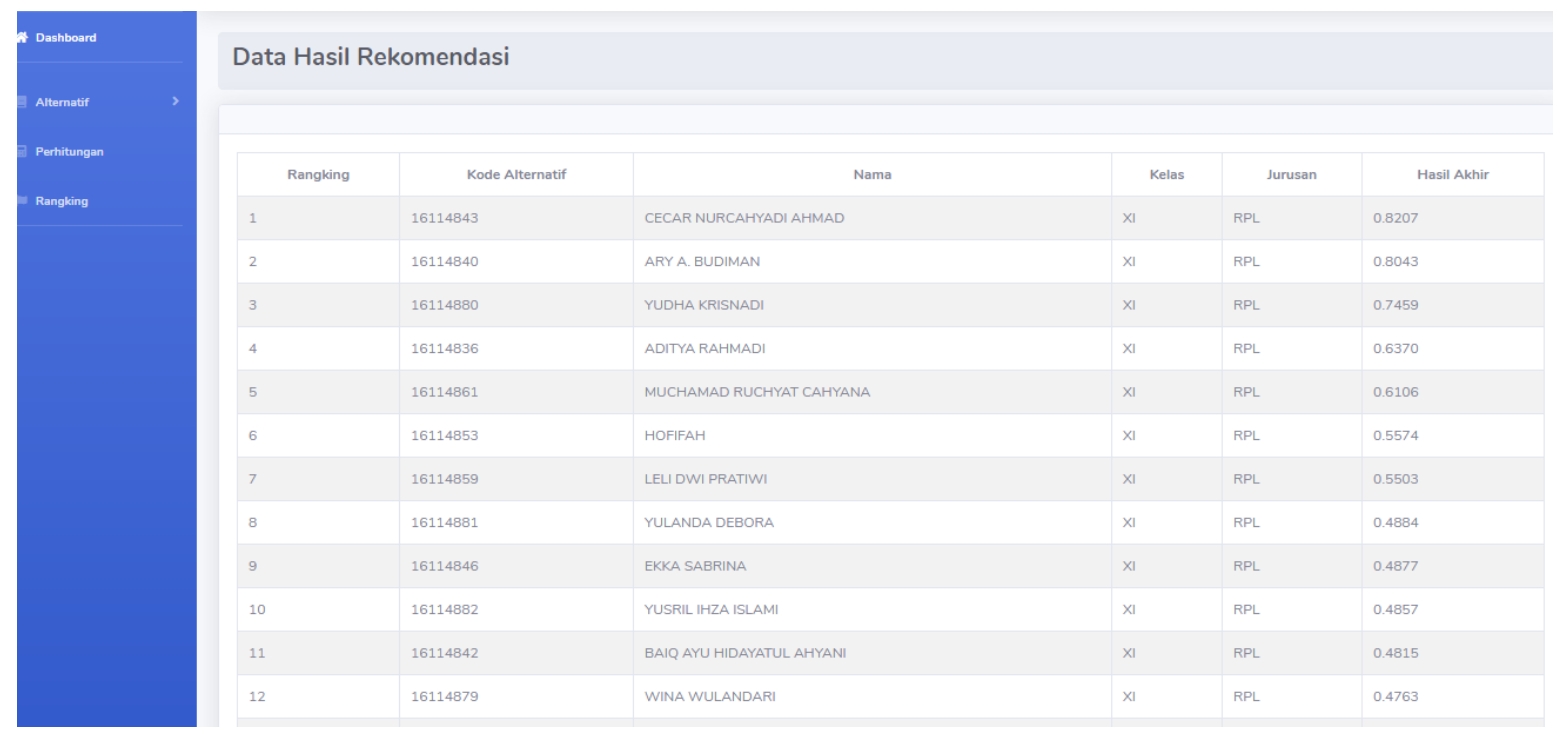

Gambar 4. Hasil Perangkingan Sistem Rekomendasi Penerima Beasiswa

Aplikasi sistem pendukung keputusan menggunakan kombinasi metode AHP dan TOPSIS dapat digunakan untuk rekomendasi penerima beasiswa siswa SMK Negeri 2 mataram. Metode AHP digunakan untuk pembobotan secara otomatis dan mendapatkan bobot prioritas antar kriteria yang digunakan, untuk minimalisir terjadinya pembobotan secara subyektif. Sedangkan metode TOPSIS digunakan untuk melakukan perangkingan penerima beasiswa dengan cara mengoptimalkan solusi ideal positif dan solusi ideal negatif untuk mendapatkan penerima beasiswa yang tepat dan layak. Dengan adanya sistem Pendukung keputusan rekomendasi penerima beasiswa tersebut dapat memudahkan dan mempercepat pihak pengambil keputusan (pihak humas) dalam seleksi penerima beasiswa dengan transparan dan okjektif. Adapun hasil validasi perhitungan secara sistem maupun manual menghasilkan hasil perangkingan alternatif yang sama.

\section{KESIMPULAN}

Beasiswa merupakan bantuan biaya pendidikan yang diberikan kepada penerima yang layak dan tepat berdasarkan ketentuan dari beasiswa itu sendiri. Dalam menenetukan penerima beasiswa pihak sekolah melakukan seleksi dan verifikasi berkenaan dengan data calon penerima beasiswa. Seleksi dan verifikasi manual memiliki proses yang panjang dan membutuhkan waktu yang lama dalam menenetukan penerima beasiswa. Selain itu seleksi manual cenderung terjadi tidak transparansi dan tidak objektif. Sistem pendukung keputusan merupakan salah satu solusi 
dalam permasalahan ini. Dalam sistem pendukung keputusan terdapat beberapa kriteria yang merupakan acuan dalam menentukan penerima beasiswa yang layk dan tepat. Kriteria dalam menentukan penerima beasiswa pada SMK Negeri 2 Mataram antara lain : nilai rata-rata, penghasilan orang tua, tanggungan orang tua, jarak tempat tinggal dengan sekolah, serta kehadiran siswa. Selain kriteria, terdapat metode sistem pendukung keputusan yang digunakan dalam menenetukan penerima beasiswa adalah kombinasi antara metode AHP dan metode TOPSIS. Metode AHP digunakan untuk pembobotan secara otomatis dan mendapatkan bobot prioritas antar kriteria yang digunakan, untuk minimalisir terjadinya pembobotan secara subyektif. Sedangkan metode TOPSIS digunakan untuk melakukan perangkingan penerima beasiswa dengan cara mengoptimalkan solusi ideal positif dan solusi ideal negatif untuk mendapatkan penerima beasiswa yang tepat dan layak. Hasil penentuan bobot terhadap kriteria menggunakan menggunakan metode AHP mendapatkan nilai Consistency Ratio $(\mathrm{CR})=\mathbf{0 , 0 1 2 2}$. Berdasarkan nilai CR yang dihasilkan $<0,1$ maka bobot setiap kriteria dapat dikatakan konsisten. Sehingga bobot yang didapatkan menggunakan metode AHP dapat digunakan. Selain itu, metode AHP dapat menentukan bobot prioritas antar kriteria, sehingga mengetahu urutan kriteria-kriteria yang krusial dalam menenetukan penerima beasiswa. Dalam hal ini kriteria yang memiliki bobot paling berpengaruh adalah kriteria harga dengan bobot 0,4624. Sedangkan metode TOPSIS dilakukan untuk menenetukan solusi ideal posisitif sebagai nilai terbaik dan solusi ideal negatif sebagai nilai terburuk, kemudian dilakukan proses perhitungan jarak nilai dari masing-masing siswa dengan nilai terbaik atau solusi ideal posisitif. Dari proses penentuan perangkingan dengan menggunakan metode TOPSIS tersebut didapatkan siswa yang berhak mendapatkan beasiswa dengan berdasarkan nilai tertinggi yaitu Cecar Nurcahyadi $=0.8197$, Arya Budiman $=0.8036$, Yudha Krisnadi $=0.7482$, dan seterusnya . Dengan adanya Sistem Pendukung Keputusan sebagai rekomendasi dalam menentukan penerima beasiswa tersebut dapat memudahkan dan mempercepat pihak pengambil keputusan (pihak humas) dalam seleksi penerima beasiswa dengan transparan dan okjektif. Selain itu, sistem ini dapat digunakan kembali pada proses seleksi dan verifikasi penerima beasiswa di periode selanjutnya tanpa harus mengulang dari proses awal.

\section{REFERENCES}

[1] A. S. Suweleh, D. Susilowati, and Hairani Hairani, "Aplikasi Penentuan Penerima Beasiswa Menggunakan Algoritma C4.5,”. Jurnal BITe, vol. 2, no. 1, pp. 12-21, 2020.

[2] H. Hairani, A. S. Suweleh, and D. Susilowaty, "Penanganan Ketidak Seimbangan Kelas Menggunakan Pendekatan Level Data," Jurnal Manajemen, Teknologi Informasi dan Rekayasa Komputer, vol. 20, no. 1, pp. 109-116, 2020, doi: 10.30812/matrik.v20i1.846.

[3] Y. I. Kurniawan, D. Pungki, and A. Windiasani, "Sistem Pendukung Keputusan untuk Penentuan Kelolosan Beasiswa Sekolah Menengah Kejuruan (SMK) Menggunakan Metode Fuzzy,” Jurnal Teknik Elektro, vol. 9, no. 1, pp. 13-17, 2017.

[4] R. Roni, S. Sumijan, and J. Santony, "Metode Weighted Product dalam Pemilihan Penerima Beasiswa Bagi Peserta Didik,” Jurnal RESTI (Rekayasa Sistem dan Teknologi Informasi), vol. 1, no. 3, pp. 87-93, 2017.

[5] B. Subaeki, M. Irfan, R. S. Adipradana, C. N. Alam, and M. A. Ramdhani, "Decision support system design of higher education scholarship recipients with android-based," in Journal of Physics: Conference Series, Nov. 2019, vol. 1280, no. 2, pp. 1-6, doi: 10.1088/1742-6596/1280/2/022016.

[6] R. Andriani, R. F. Amanullah, D. Ninosari, and Kusrini, "Optimization of Clustering Algorithm on Decision Support System of Scholarship Recipients Using Analytical Hierarchy Process Method," in Journal of Physics: Conference Series, Dec. 2018, vol. 1140, no. 1, pp. 1-9, doi: 10.1088/1742-6596/1140/1/012028.

[7] T. Noviyanti, "Sistem Penunjang Keputusan Dalam Penerimaan Beasiswa PPA Menggunakan Metode Analytic Hierarchy Process (AHP) (Studi Kasus: Universitas Gunadarma)," J. Ilm. Teknol. dan Rekayasa, vol. 24, no. 1, pp. 35-45, 2019, doi: 10.35760/tr.2019.v24i1.1932.

[8] L. Laurentinus, "Sistem Pendukung Keputusan Seleksi Mahasiswa Penerima Beasiswa menggunakan Metode Fuzzy Multiple Attribute Decision Making (FMADM) dan Simple Additive Weighting (SAW)," InfoTekJar (Jurnal Nas. Inform. dan Teknol. Jaringan), vol. 4, no. 1, pp. 133-137, Sep. 2019, doi: 10.30743/infotekjar.v4i1.1559.

[9] N. Faizah, D. Prastiyanto, and S. Seno Adi, "Implementasi Metode Simple Additive Weighting pada Sistem Pendukung Keputusan Penerima Beasiswa,” Edu Komputika J., vol. 4, no. 1, pp. 55-61, 2017, [Online]. Available: http://journal.unnes.ac.id/sju/index.php/edukom.

[10] A. Topadang, I. Irwansyah, and S. Safruddin, "Penerapan Metode Simple Additive Weighting(Saw) Untuk Pemilihan 
Beasiswa Kurang Mampu Pada Sekolah Dasar Katolik Hati Kudus Samarinda,” Just TI (Jurnal Sains Terap. Teknol. Informasi), vol. 12, no. 2, p. 66, Jul. 2020, doi: 10.46964/justti.v12i2.377.

[11] M. M. D. Widianta, T. Rizaldi, D. P. S. Setyohadi, and H. Y. Riskiawan, "Comparison of Multi-Criteria Decision Support Methods (AHP, TOPSIS, SAW \& PROMENTHEE) for Employee Placement," in Journal of Physics: Conference Series, Feb. 2018, vol. 953, no. 1, pp. 1-5, doi: 10.1088/1742-6596/953/1/012116.

[12] A. Arifin and R. A. Fadillah, "Implementasi Metode Attribute Decission Making (MADM) untuk Menentukan Kawasan Penanaman Bakau,” J. Sains, Teknol. dan Ind., vol. 14, no. 1, pp. 86-92, 2016.

[13] A. Pujianto, K. Kusrini, and A. Sunyoto, "Perancangan Sistem Pendukung Keputusan Untuk Prediksi Penerima Beasiswa Menggunakan Metode Neural Network Backpropagation,” J. Teknol. Inf. dan Ilmu Komput., vol. 5, no. 2, pp. 157-162, May 2018, doi: 10.25126/jtiik.201852631.

[14] A. Sumiah and N. Mirantika, "Perbandingan Metode K-Nearest Neighbor dan Naive Bayes untuk Rekomendasi Penentuan Mahasiswa Penerima Beasiswa pada Universitas Kuningan,” Buffer Inform., vol. 6, no. 1, pp. 1-10, 2020.

[15] W. Supriyanti, "Rancang bangun aplikasi sistem pendukung keputusan penerima beasiswa dengan metode SAW," Creat. Inf. Technol. J., vol. 1, no. 1, pp. 67-75, 2013.

[16] N. G. Perdana and T. Widodo, "Sistem Pendukung Keputusan Pemberian Beasiswa Kepada Peserta Didik Baru Menggunakan Metode TOPSIS," in Seminar Nasional Teknologi Informasi \& Komunikasi Terapan 2013 (Semantik 2013), 2013, pp. 265-272. 